[Published in: Georg Meggle (ed): Ethics of Terrorism and Counter-Terrorism. (Franfurt/Lancaster: Ontos Verlag, 2005), pp. 39-50].

\title{
Benign Blackmail
}

\author{
Cassandra's Plan or What Is Terrorism?
}

\section{Olaf L. Müller (www.gehirnimtank.de)}

\section{TABLE OF CONTENT.}

I. The Legal Dimension

II. The Moral Dimension: An Additional Component in the Notion of Terrorism?

III. A Proposed Definition of Terrorism

IV. Is Terrorism Always Morally Wrong? A Comparison to War

V. Terrorism against Atomic War: Cassandra's Plan

VI. Concluding Remarks

References

ABSTRACT. In its reaction on the terroristic attacks of September 9th, 2001, the USgovernment threatened Afghanistan's Taleban with war in order to force them to extradite terrorist leader Bin Laden; the Taleban said that they would not surrender to this kind of blackmail - and so, they were removed from Kabul by means of military force.

The rivalling versions of this story depend crucially on notions such as "terrorism" and "blackmail". Obviously you'll gain public support for your preferrend version of the story if you are able to determine how those notions are to be used. So we had better reflect about their very meaning and about the moral implications of their proper usage. To gain a deeper understanding of our notions of "blackmail" and "terrorism" I shall propose an extreme thought experiment: Cassandra's plan.

Cassandra foresees that sooner or later one of the nuclear powers might take the liberty to use atomic bombs. From fright she founds an NGO for blackmailing the statesmen who are in charge of nuclear weapons; she announces in public that all ministers and leaders of any government shall be hunted down, and executed, whose soldiers drop but one atomic bomb. (Cassandra's NGO keeps killer teams in constant training so as to increase the effect of the threat; this is being financiated from private donations).

In my paper I shall raise two questions (without claiming to provide definite answers). First, would we have to say that Cassandra's NGO was a terrorist organisation? Second, would it be morally wrong if Cassandra blackmailed statesmen in the way indicated?

NOTE. This electronic text differs from its official counterpart (both typographically and with respect to layout). 


\title{
Benign Blackmail
}

\section{Cassandra's Plan or What Is Terrorism?'}

\author{
Olaf L. Mueller (Humboldt University, Berlin)
}

What do we mean when we label an activity "terrorist"? And what is the appropriate ethical evaluation of such activity? These are the two questions which I intend to address in the present paper. One of my aims is to convince you that even if a certain course of action is deemed "terrorist", it is still an open question whether or not that very course of action is morally wrong. My second aim is to show that strict condemnation of terrorism implies pacifism.

\section{The Legal Dimension}

On first sight there appear to be normative as well as descriptive aspects in the notion of terrorism. Since the normative aspects tend to provoke greater controversy, we shall begin our discussion with them and save the descriptive aspects for a briefer and later discussion (section III).

The first question which comes to mind when thinking about terrorism and its normative aspects is of course: What kind of norms are involved-legal norms, moral norms, or both? In the present section, I will begin to answer this question by concentrating on the legal norms involved and by tracing the analytic connections between these norms and the notion of terrorism. In the following section, I will then proceed to show that moral norms need not necessarily be invoked when defining terrorism.

"Terrorist activity emerges from the underground". I think this is a truism which expresses well what most people feel to be the most important-and most frightening-aspect of terrorism. However, talk about "the underground" is merely a metaphor. How should we understand it? Invisibility comes perhaps first to mind here, but I propose not to follow this

1 This paper is the substantially changed version of a talk I delivered at the conference Ethics of Terrorism and Counter-Terrorism (ZiF, Bielefeld, October $28^{\text {th }}$, 2002). I am grateful to Michael Haarkötter, Sybille Haupt, Thomas Schmidt, Matthias Schote, Cassandra da Troia, and Sylwia Trzaska for controversial discussions of the ideas from which this paper originated. Thanks to Cynthia Myers for linguistic advice. Last but not least, I would like to thank the symposion's participants for both challenging and constructive criticism. 
line because terrorist activity can be quite visible. It seems to me that underground activity is first of all illegal; it involves breaking the law. (And of course, the best way to succeed in breaking the law is to do it invisibly; invisibility is a good strategy for people outside the law). Less metaphorically, then, our truism can be put as follows:

Terrorism is, by definition, unlawful.

You may ask: "Unlawful" under the laws of whom? This is indeed a crucial question because our truism leaves room for interpretation, and hence for political exploitation. In other words, the truism runs the danger of playing into the hands of those who invoke the notion of terrorism in order to defend a given legal or political order against violent attempts at change - and it runs the danger of playing into the hands of those who wish to impose their own legal order on everybody else.

The danger is real. It lurks, for example, in an official US-American document which defines terrorist activity as

Activity [...] which, if committed in the United States, would be unlawful under the laws of the United States [...] (US-Office of the Coordinator for Counterterrorism). ${ }^{2}$

In order to avoid the severe political (if you want, imperialistic) implications of such a passage, one might be tempted to divorce the notion of terrorism from the legal codex of individual countries. One might choose instead to change the notion of terrorism such that it signifies an activity which (in one's opinion) is simply "immoral" (and which, in addition, falls under certain non-normative descriptions to be discussed later). With such a notion of terrorism the tables are suddenly turned, and it is now only one small step to detecting "terrorism" in the US-Office of the Coordinator for Counterterrorism, in the entire US foreign policy, that of its allies, its armies, secret services etc.

I have three arguments against this way of speaking. First, the inflated usage of the term "terrorism" diminishes its significance and informational value. When used in such a loose manner, the term is devalued to the point of becoming a mere propaganda slogan - unapt for serious, rational discussion.

2 See the "2001 Report on Foreign Terrorist Organizations", released by the Office of the Coordinator for Counterterrorism, October 5th, 2001. (The formulation quoted above occurs also in the Immigration and Nationality Act). 
But secondly, even if you apply the term "terrorism" with more self-discipline than in (my caricature of) leftwing propaganda, you will still cause confusion and fruitless quarrelling about words as long as you use the term "terrorist" as a way to morally criticize-let us say-governments. Moreover it is not necessary to call a government a terrorist government if you wish to criticize it; rather it suffices to state the moral criticism directly, without invoking the term "terrorism".

This leads us to my third reason for not divorcing the term from its legal connotations: Such a divorce is not the only way to counter the US-Coordinator for Counterterrorism and his deplorable definition of terrorism. He and his combatants are only capable of exploiting this term as long as it is taken for granted that terrorism is eo ipso morally wrong and must be fought against. What makes the term dangerous is not its legal connotations alone, but rather the lumping together of its legal and ethical connotations. Once we manage to free the notion of terrorism from ethical connotations altogether, the notion becomes much more difficult to exploit.

In the next section I will demonstrate (on linguistic grounds) that the supposed marriage between terrorism and ethical considerations has been invalid from the start. I will prepare the grounds in the remainder of this section by returning to our initial truism

Terrorism is, by definition, unlawful, and to the question which we posed but have not yet fully addressed:

"Unlawful" under the laws of whom?

There is only one way to approach this question without bias - and that is to relativize. I would like to propose that an act can only be considered "terrorist" relative to the laws of a given country. Of course, in a derivative sense, it is possible to call a terrorist act absolutely terrorist if it is considered unlawful under the laws of every country. Or we can speak of terrorism relative to the laws of Western democracy. But whether or not we employ derivative notions of terrorism or stick to the original, relative notion, we can only gain clarity in our discussions about terrorism when we explicitly state whose laws we have in mind when we use the term.

And the clarity so gained will have a side-effect which we should welcome: It will prevent us from hasty moral judgments since we are all (I hope) aware that reference to some country's legal system alone is morally irrelevant. 
To be sure, I do not intend to imply that all legal systems are morally on a par. What I have said implies only that legal considerations (within, say, our own political order) cannot replace moral considerations - even when we speak about terrorism.

\section{The Moral Dimension: An Additional Component in the Notion of Terrorism?}

In the preceding section I first appealed to the truism "Terrorist activity emerges from the underground" in order to convince you that the norms to be invoked when defining terrorism must be of a legal sort. I also indicated that it would be politically dangerous to invoke moral norms when defining terrorism. Someone could of course object to this latter point and argue that when explicating a given term, undesirable political consequences should not play any role whatsoever: An explication must be sensitive to the actual usage of the term in question, even if certain political dangers do in fact result.

Fair enough; let us look at actual linguistic practice and try to determine whether or not our notion of terrorism might have ethical aspects after all. The following proposal is at issue:

"By definition, an activity is terrorist if it falls under such and such description [to be specified], and if, in addition, it is immoral".

To refute this proposal I want to direct our attention to three characteristics of the way we use the term "terrorism".

(a) In everyday language, it is easier to agree that a given act is terrorist than to agree that the very same act is immoral.

For example, during the Seventies and Eighties there was a far-reaching consensus in West Germany that the members of the Red Army Fraction (RAF) were terrorists. (If I am not mistaken, the RAF is still a paradigm case of terrorism in the eyes of most Germans). Nevertheless there have been quite a few debates in which it was not taken for granted that the terrorist RAF actions deserved unequivocal moral condemnation. Although the majority of Germans have thought that they deserve to be morally condemned, there has been a small number of people who have not agreed that the RAF actions, which they themselves have labeled "terrorist", were immoral. This would not be the case if moral condemnation was part of the meaning of the term "terrorism".

It is important to see that by simply providing one example of this sort I have already proven my point. I do not imply that whenever people agree to call a certain activity "terrorist" there is always ethical disagreement about the act in question (the attack on the Twin Towers could 
be well cited as a perfect counterexample for such a broad claim). I am only urging that it is possible to label an activity "terrorist" without implying that that particular activity is also immoral. For my purposes it suffices to insist that not all attributions of terrorism are in this respect similar to the example of September 11th.

Someone could counter that the example of linguistic usage cited above to prove my point is not convincing because it exemplifies a deviant usage of language, or worse, a misuse of language. And indeed, isn't it a little suspicious to cite linguistic behavior of an extremely small group of political radicals in order to analyze our notion of terrorism? Had we not better take a closer look at our own linguistic habits?

This is a sensible suggestion. It brings us to my next piece of linguistic evidence (which parallels G.E. Moore's famous argument of the "open question", see Moore [PE]:66-68 $(\S 13))$ :

(b) We are not puzzled when we hear someone saying: "This is an act of terrorism, but is it morally wrong?"

Let us focus on our own reaction to someone else's questions of that sort. I claim that we do not react as if we are witnessing linguistic incompetence. Rather we feel dragged into moral controversy, which could not be the case, if we did not understand what our interlocutor meant to say in the first place.

It could, for example, be the case that the speaker approves of the good motives behind the terrorist act in question and that she subscribes to a moral point of view in which nothing else matters but the agent's motives. We can understand this point of view even if we do not share it.

My third piece of linguistic evidence which speaks against including issues of morality in the definition of "terrorism" is connected to the two linguistic observations we have been looking at:

(c) A terrorist can describe her own acts as "terrorist"—and nevertheless insist that the very same acts are morally good.

Self-ascriptions of terrorism occur quite frequently. If the meaning of the term "terrorism" contained an element of moral condemnation it would follow that any self-ascription of terrorism would entail moral self-accusation. To be sure, it may well be that a terrorist considers her own deeds morally wrong. But this is not the rule. (And if it occurs, then 
usually from an ex-post perspective, which is in a way external). Are terrorists, who call themselves so, insensitive to moral considerations, then? Quite the reverse. I believe that often they are sensitive to moral considerations-but unfortunately they are sensitive to moral considerations which most of us find preposterous. They picture themselves as being driven by morals. And if this is compatible with self-ascriptions of terrorism then obviously moral condemnation cannot be a part of what is meant by that word. To the contrary, the word's meaning seems to include the morality of the agent's motives - in the eyes of the agent herself. Unlike ordinary criminals she does not break the law for personal gain but because her motives are directed to something "higher". Although this may be considered a moral component in the notion of terrorism, it is, strictly speaking, an element of description: it describes which moral quality the terrorist attributes to her own motives.

If we were to summarize the results from sections I and II, we would have to say that terrorist activity emerges when moral motivations lead an agent to break the positive law. Both legal and moral norms are involved when we speak of terrorism - but the latter are involved only on a purely descriptive level: What happens to be the law of such and such a country is violated due to motives, which agent so and so happens to find morally superior.

This is not yet a complete definition of terrorism because there are-for example, nonviolent-ways of breaking the law for moral reasons which cannot be subsumed under the label "terrorism". To complete our account we have to include an element that highlights the role of violence and horror in terrorist activity. Here, then, is my complete proposal:

\section{A Proposed Definition of Terrorism}

By definition, any illegal use (or threat) of violence is terrorist activity if

(a) it is performed in the light of motives which the agent considers morally good (rather than for mere personal gain);

(b) its aim is directed against a given legal or political order (or decision);

(c) it tries to reach that aim via horrifying those who benefit from, are involved in, or support the order (or decision) in question. ${ }^{3}$

This proposal needs some comment. First of all: According to the definition, legal use of violence cannot be labeled "terrorist". It can however be morally equivalent to terrorism. As

3 There are, of course, more possibilities of defining "terrorism". My definition covers what Georg Meggle calls political terrorism in the broad sense, see Meggle [TGT], sections 1.5-1.6. 
we shall see in the next section, it is even possible for legal political action to be morally worse than terrorism. My definition is morally neutral.

Secondly: According to part (b) of our definition, the aim of terrorist activity need not be constructive. I think this captures well how we speak and think about terrorism. Terrorism is destructive rather than constructive. When we call an activity terrorist we do not need to know much about its positive or constructive goals. And yet it would seem strange if we couldn't at least tell against whom or what the terrorist act was directed.

True, it could very well be the case that we know more than that. But even when we know something about the terrorist's positive goals, we are likely to know much more about her negative goals. This is because the terrorist thinks she can reach her positive goals only on the via negativa - by way of removing hindrances. Destruction comes first on the terrorist agenda. If we want to put the same point less tendentiously we might choose to say that the terrorist is essentially interested in initiating changes; the actual, positive result of the change comes later and need not play a prominent role in the terrorist's deliberations and activities.

Once we look at things from this perspective it becomes obvious that the destructive aspect of terrorism might not necessarily lie in the terrorist's goals. This leads us to my last comment, which concerns part (c) of our definition. In my understanding, terrifying people through horrific acts need not be the ultimate goal of terrorists; rather and as a rule, it is supposed to be an effective means to some other goal. This is not to say that horrifying people cannot be the ultimate goal of a terrorist act. The attack on the Twin Towers is perhaps the best example of terrorism where no other goal was present than the goal of terrifying a complete city. Still I want to insist that this extreme case is the exception and that there can be and indeed are numerous cases of terrorism where horror is not the final goal of the act but merely an instrument.

\section{Is Terrorism Always Morally Wrong? A Comparison to War}

In the previous sections I have proposed an understanding of terrorism that gives us semantic room for attributing the term "terrorism" without built-in moral disapproval. The sentence "Terrorism is always morally wrong" is not an analytic truth. Still the sentence might be true; it might be the case that all instances of terrorism just happen to be morally wrong. So our next question must be: Is terrorism always morally wrong? 
I want to consider four possible reasons for believing that the answer should be to the positive. These reasons will later turn out to be inconclusive; yet this is not my main concern at present. Rather I hope to show that those reasons - if convincing - not only provide moral ammunition against terrorism, but against war as well. The lesson from this will be that strict counter-terrorism implies pacifism. This is most easily seen with respect to the first moral reason against terrorism:

(a) "Terrorism is always morally wrong just because it involves violence".

Those who find this convincing have to claim that violence is always morally wrong no matter what the case. Since this carries over to any military action, such arguments imply a strictly pacifistic position. I have nothing to say against strict pacifism in the present paper. I only want to remind you that reason (a) has quite extreme implications and cannot be appealed to by those who support a war against terrorism.

Be that as it may, you might find counter-terrorist reason (a) too extreme, because you believe that violence should be permissible at times - at least in cases where it is directed against criminal mass murderers and where there is no other way to prevent the worst. This may lead you to contemplate our next counter-terrorist reason, which is less extreme than the previous one.

(b) "Terrorism is always morally wrong because de facto it always involves violence against innocent people (that is, against people who have nothing to do with the political order or decision against which the terrorist act in question is directed)".

This moral reason against terrorism is compatible with permitting limited usage of violence in police action. But again, it is incompatible with any actual instance of military action. Violence against innocent people seems more characteristic of military than of terrorist action. (Some of the German RAF's first terrorist activities, for example, were committed without great danger to innocent people, see Aust [BMK]). Let me be more specific about this: There have been many military enterprises in recent history whose death poll among civilians was much higher than in the case of, say, the Western intervention in Kosovo during 1998. But there have not been many terrorist courses of action whose lethal effects among "innocent people" have reached a comparable dimension. ${ }^{4}$ Surely, there have been some

4 Such comparisons may seem to depend on a prior decision as to how many seperate terrorist acts are to be considered a complete "terrorist course of action". (A terrorist underground war, for example, may last many years, and the longer it lasts, the more victims it is likely to produce). I think, however, that even if we look at complete civil wars (in which often one side labels the other one "terrorist"), we must admit that their consequences tend to be less disastrous than the consequences of ordinary, 
terrorist acts of that dimension; the attack on the Twin Towers is a case in point, yet its dimension is the exception, not the rule.

To prevent misunderstandings, I do not mean to imply that since we have become accustomed to collateral damage in the course of military action we should stop complaining about the victims of an average terrorist atrocity. The point is intended to mean just the opposite: If we cannot and do not want to accept terrorist activity because of its lethal consequences for innocent victims, then, a fortiori, we should also be against war because there the situation is far worse.

For those who wish to prevent inferring strict pacifism from moral counter-terrorism it might be helpful to try and detect crucial ethical differences between military and terrorist actions. One such difference is of course that terrorism emerges from the underground while war can be quite official. Does this difference matter when considering the morality of the deed in question? According to our next counter-terrorist reason, it does:

(c) "Terrorism is always morally wrong because it involves illegal violence".

This view is implausible, because it implies what one might call strict legalism: "Whatever is illegal within a given legal order is eo ipso morally wrong". We should never subscribe to views of this sort, since we know all too well that there can be and have in fact been legal systems so wicked that obedience to their positive laws must be considered evil.

The counter-terrorist of our time, who is sensitive to this observation, does not have to give up yet. She does not need to be opposed to all varieties of terrorism; she can content herself with being opposed to the branch of terrorism which matters the most to us (the citizens of Western democracy). She can restrict her counter-terrorist reasoning so as to be only directed against terrorism relative to the Western democracies. As a result, she will only have to refer to our legal systems - thus circumventing the unfortunate reference to all systems of law, even to the evil ones, which troubled us in (c). The result is this:

(d) "Terrorism relative to our Western democracy is always morally wrong because it involves action which is unlawful under a law with moral backing".

I believe that this is a counter-terrorist point of view which many Western citizens find plausible. To be sure, it is not a view which disapproves of terrorism tout court. Therefore, it is less vulnerable to criticism than the counter-terrorist reasons considered earlier. Let us,

official wars between nations. (For a similar observation see Schleichert ([MSIo], section 2), who refers to Schlick ([NK]:101). 
however, see what happens when we bring the issue of military action and warfare into play again. As we shall see, doing so appears to shake the robust trust in the moral superiority of our own legal systems.

True, Western legal systems pay high regard to the value of human life-at least to that of their own citizens (and to that of those who happen to be within their borders). But it must be admitted that these high standards are not granted world-wide. It may happen that legal procedures within our own countries lead to decisions and activities of disastrous consequence outside these very same countries. Military action "out of area" is the most prominent example of that sort. And once we reflect on the fact that atomic warfare is still legal under the laws of (at least some of) the Western countries, we may hesitate before subscribing to Western legalism (as exhibited in counter-terrorist reason (d)).

Let us try to test these intuitions by means of an extreme example, which I shall call Cassandra's Plan. My friend Cassandra has founded a terrorist organization whose exclusive goal it is to prevent atomic warfare. A noble goal indeed, if it were not for the henous methods involved...

When Cassandra first told me about her plan I immediately thought to myself: Her organization could be considered one of the best counter-examples-I have ever come across - for the claim "Terrorism (relative to the Western democracies) is always morally wrong".

\section{Terrorism against Atomic War: Cassandra's Plan}

Let me begin by quoting some crucial passages from an underground paper which Cassandra wrote for fund-raising purposes. As we shall see, Cassandra seems to be quite pessimistic about recent history:

"As a matter of good coincidence, the world's political leaders have abstained from the military usage of nuclear weapons for the last 56 years. There is no guarantee that this will continue to be so for the next 50 years".

In the text which follows Cassandra cites examples of major leaders who were tempted to play with atomic fire for military reasons. The examples range from 1962 (the time of the Cuban Missile Crisis) to the present. Cassandra includes analyses of the British war in the Falklands, of the conflict between Pakistan and India, and addresses the alarming question as to what has become of the former Soviet Union's nuclear arsenal. It is in fact the end of the 
Cold War which troubles Cassandra the most. She is afraid that the only remaining superpower might someday find it convenient to solve certain military problems with nuclear arms. Cassandra invites us to reflect briefly on the recent counter-terrorist war in Afghanistan: When entire terrorist armies remain undetected in a labyrinth of mountain caves, then surely a well-placed atomic explosion would put an end to the matter, wouldn't it? According to Cassandra it is precisely considerations of this sort which have already led to a change of strategic doctrine in the United States. So-called "mini-nukes"—atomic arms of limited effect - are being developed so as to increase the options for restricted atomic warfare. ${ }^{5}$

Not too many people seem worried by this. We are so accustomed to the non-usage of nuclear arms that we can hardly imagine being woken up by an abrupt change. But Cassandra's imaginative powers are not asleep, otherwise she wouldn't be Cassandra. The question is, should we diagnose Cassandra with hysterical pessimism-or rather with reasonable realism? Looking at her list of examples, I cannot help thinking that it would be a miracle if in the future (say, within the forthcoming five decades) we were not made to witness the military usage of nuclear arms. Needless to say, Cassandra refuses to believe in miracles. Her next step is what I call Cassandra's moral axiom:

"Any military usage of nuclear weapons is evil and must be prevented at [almost] any price. (We should not wish to lead our lives in a world where a third atomic catastrophe has been produced for military reasons)".

Cassandra does not really try to prove her moral axiom. Her paper is addressed to people who find it obvious that nuclear warfare is perverse.

There is of course always going to be a small group of people who do not want to subscribe to Cassandra's axiom, and I do not think these people are likely to be convinced by moral reasoning alone. Perhaps it would therefore be more effective to make them see and feel what unheard-of evil was brought about by atomic explosions in Hiroshima and Nagasaki in 1945. This is a task for historians, museum directors, biographers, photographers, painters, poets, and film-makers. But as I have said, Cassandra's concern lies somewhere else. I propose joining Cassandra to see what her moral axiom implies for those who subscribe to it.

Cassandra does not succumb to fatalism. She wants to prevent the nuclear danger that she alone sees lurking. But how? Here is what she has learned from Western nuclear strategy (as practiced during the Cold War Era):

5 See Bromley et al [BB]. 
"Deterrence by means of mutually assured destruction may decrease the probability of atomic warfare".

In Cassandra's eyes it is more than a little dubious to gamble in such a way with the survival of the whole human race. (And anyway, such a game is beyond Cassandra's powers). Still she thinks that some deterrence, or blackmail, might be helpful in preventing a third nuclear catastrophe. At this point Cassandra comes up with an innovative idea:

"It would be sufficient to direct the effects of deterrence precisely towards those who decide about military usage of nuclear weapons".

The crucial question is, who exactly must be the target of Cassandra's threat? Her answer is quite simple. It is first of all governments who are in charge of and responsible for nuclear arms. Thus she thinks it most promising to issue an announcement of the following sort to all members of government of the nuclear powers:

"We have founded an NGO whose aim it is to compel all leaders and governmental members of the nuclear powers to abstain from the actual usage of nuclear weapons. In the event that the soldiers of a nuclear power drop but one atomic bomb, our killer teams shall hunt down and execute this government's ministers and its leader".

We may well doubt whether this would be sufficient. There have been crazy politicians in the past and there may be crazy ones in future. Happily, however, most politicians care about their own well-being. They are likely to avoid decisions which will produce the life-long danger of assasination, since such a threat would turn their lives into a living nightmare even if the assassination itself could be prevented. The nightmare Cassandra has in mind here does not spring solely from her imagination but also from very recent history; Salman Rushdie lived through it. It does not seem that an impossible sum of money is needed to produce similar effects on politicians.

If Casssandra's threat could be made credible (which in her mind is only a matter of sufficient financial backing), it would certainly diminish the danger of nuclear warfare. True, it would not erase the danger altogether; just think of crazy politicians again — or of soldiers out of government control. Cassandra does not pretend to have a solution for stopping them. Her ambition is more modest. Her ambition is to make the world a safer place-safer at least for those of us who do not belong to certain governments. She admits that it appears a little unfair to threaten without difference all members of government of the nuclear powers. But then, justice is not her concern. She wants to issue a threat which is effective, clear-cut, and easily understood. And she wishes to avoid endless discussions about the targets of action, 
should it turn out that her threat was ineffective. In this case, Cassandra will announce the following:

"The following people belong to the government which is responsible for yesterday's atomic explosion: [List of names to be inserted]. Each of them was priorly informed about our plan of action; each of them was free to resign from his post before the fatal decision was made. From now on, they are to be considered outlaws, they are to be hunted down and executed. WARNING to secretaries, bodyguards, drivers, friends, and family members: We cannot guarantee for your safety as long as you stay in the vicinity of the people listed above".

This is Cassandra's final announcement; her next steps will be non-verbal.

\section{Concluding Remarks}

Cassandra's NGO is unlawful (under the law of the Western democracies), it involves violence (or the threat of violence), its motives are honorable (at least when judged from Cassandra's own perspective), and it tries to reach its political aim by means of terrifying statesmen, especially those from the Western democracies. ${ }^{6}$ Therefore, Cassandra's NGO is a terrorist organization (in the sense of "terrorism" that was defined in section III). The NGO is a terrorist organization relative to the laws of the Western countries.

Question: Is Cassandra's plan morally wrong? I can see three possible views for those who think so and who nevertheless subscribe to Cassandra's moral axiom:

(a) You have complete trust in the moral wisdom of Western military policy and find Cassandra's NGO superfluous or even disturbingly dangerous.

This I find a little naive, and I do not think that I have to say much more against it.

(b) You do not have moral objections to the military logic of deterrence, or to the war against terrorism in Afghanistan, or to the Western threats against Iraq, or to some of the Western humanitarian interventions (such as in Kosovo); but you find Cassandra's plan morally wrong.

To me it appears difficult to formulate this view in any coherent way. What exactly is the essential difference between Cassandra's methods and ordinary military practice? The main difference seems to be that Cassandra's NGO is not an official army, and thus, cannot be controlled legally. But Cassandra finds the legal control of those who might decide in favor

6 Her threat is, of course, also directed to the statesmen of Russia, India, Pakistan etc. I neglect this aspect of her threat because we are interested in terrorism relative to the 
of nuclear warfare to be insufficient. And: Her plan is much less dangerous for civil populations than almost any military action.

(c) You find Cassandra's plan brutal, inhuman, cruel, full of hatred, and thus, morally unacceptable.

In my eyes this view is correct. It is an accurate and convincing moral description of Cassandra's plan. The creator of the plan exhibits a frame of mind which I find deplorably cynical. To see this I propose that you look, for example, at the brute way she exploits Salman Rushdie's fate - a fate that ought to elicit our solidarity and sympathy.

Of course, utilitarians and consequentialists will not be disturbed by observations of this kind. And although I think their position is wrong, it would go beyond the scope of this paper to present a full-fledged argument against their way of calculating moral issues. ${ }^{7}$ I can only ask them to imagine what it would be like if they themselves were to found or belong to an NGO like the one projected by Cassandra. Even if you do not find the personal danger involved in belonging to such an NGO frightening, ask yourself the following question:

Would you like to be the sort of person who is capable of playing Cassandra's part? Would you like to be as fanatic as Cassandra and her friends?

Let me conclude the paper with a comment for those who (like me) disapprove of Cassandra's plan because in their eyes it exhibits an inhuman, cruel, cold, in short: ugly frame of mind. I invite you to look with the very same eyes at whatever military action you wish. If I am not mistaken you will discover Cassandra's ugly traits in all those who wage war - the same traits, but escalated. The politician who initiates military action differs from Cassandra in only two aspects. He has more power, and his power is legal. The first aspect makes him more dangerous while the second does not offer any antidote for his lack of virtue. And indeed, if in the course of war he coolly risks the lives of (foreign) civilians, who have not authorized him to do so, and if in addition he calls this "collateral damage", then his lack of virtue is more than obvious. Conclusion: Terrorism is bad, war is worse.

law of Western democracy; in this context it is more significant to consider threats against the democratic leaders.

7 Elsewhere I have tried to argue against consequentialism and utilitarianism. On the one hand, I have detected an incoherence within radical forms of consequentialist or utilitarian ethics (see [CTSW]). On the other hand, I have tried to show that consequentialist or utilitarian ethics presuppose a sharp division between fact and value: a division which cannot be drawn when matters of peace and war are at issue (see $[R P])$. 


\section{References}

Aust, Stefan [BMK]: Der Baader-Meinhof-Komplex. (Hamburg: Hoffmann und Campe, Enlarged edition, 1997).

Bromley, Mark / Grahame, David / Kucia, Kristine [BB]: Bunker Busters: Washington's Drive for New Nuclear Weapons. (British American Security Information Council, Research Report 2002.2).

Meggle, Georg [TGT]: "Terror \& Gegen-Terror. Erste Ethische Reflektionen". Deutsche Zeitschrift für Philosophie 50 Heft 1 (2002), pp. 149-162.

Moore, George Edward [PE]: Principia ethica. (Cambridge: Cambridge University Press, revised edition, 1993).

Müller, Olaf [CTSW]: "Can They Say What They Want? A Transcendental Argument against Utilitarianism". The Southern Journal of Philosophy 41 No. 2 (June 2003). [Forthcoming].

Müller, Olaf [RP]: "Reconstructing Pacifism. On Different Ways of Looking at Reality". In Georg Meggle (ed) Ethics of Humanitarian Interventions. [Forthcoming].

Schleichert, Hubert [MSIo]: "Moritz Schlick's Idea of Non-Territorial States". Eröffnungsvortrag zum Symposion The Vienna Circle and Logical Empiricism (Vienna, July, 12th, 2001). [Forthcoming].

Schlick, Moritz [NK]: Natur und Kultur. (Aus dem Nachlass des Autors herausgegeben von Josef Rauscher. Wien: Humboldt-Verlag 1952). (= Sammlung die Universität, Vol. 30). 